\title{
Epigenetic toxicity and cytotoxicity of perfluorooctanoic acid and its effects on gene expression in embryonic mouse hypothalamus cells
}

\author{
Hun Kim, Min-Wook Hong, Yun-ho Bae, and Sung-Jin Lee \\ Kangwon National University College of Animal Life Sciences, Chuncheon, Korea
}

[Received in May 2021; Similarity Check in May 2021; Accepted in September 2021]

Even though the endocrine-disrupting potential of perfluorooctanoic acid (PFOA) is well known, the mechanisms underlying its cellular and epigenetic toxicity at the critical stage of hypothalamic development are poorly understood. This is why we studied its effects on the embryonic mouse hypothalamic cell line N46 (mHypoE-N46) with a hope to shed more light on the mechanisms through which PFOA causes embryonic hypothalamic cell damage. To do that, we studied cell viability, global DNA methylation, and gene expression in cells exposed to PFOA. As the PFOA dose increased, cell viability decreased, while global DNA methylation increased. PFOA also significantly altered the expression of genes related to the apoptosis and cell cycle, neurotrophic genes, and the Tet, Dnmt, and Mecp2 genes. Our findings suggest that exposure to PFOA affects cell survival through the reprogramming of embryonic hypothalamic DNA methylation patterns and altering cell homeostasis genes. DNA methylation and changes in the Mecp 2 gene expression induced by PFOA also imply wider ramifications, as they alter genes of other major mechanisms of the embryonic hypothalamus. Our study may therefore serve as a good starting point for further research into the mechanisms of PFOA effect of hypothalamic development.

KEY WORDS: cytotoxicity, DNA methylation, endocrine-disrupting chemicals, epigenetic toxicity, mHypoE-N46 cell line, PFOA

Perfluorooctanoic acid (PFOA) is a synthetic surfactant used in various industrial and consumer water- and oilresistant products with the annual production of several hundred metric tonnes since the 1950s, which makes it one of the most abundantly produced endocrine-disrupting chemicals (EDCs) worldwide (1). Its strong carbon-fluorine bond renders it highly stable and prone to bioaccumulation in the environment (2). It can easily be found in water, food, house dust, stain-resistant carpets, cookware coatings, and industrial waste (3-6). This indicates a high risk of exposure, which has been confirmed by its discovery in human blood, breast milk, and umbilical cord serum (7-11). In addition, with its average half-life in humans of 2.4 years (12), PFOA has a potential of high bioaccumulation.

Exposure to EDCs such as PFOA during early development can have lifelong detrimental effects on metabolic homeostasis and endocrine physiology $(13,14)$. However, while studies demonstrate that development of the embryonic hypothalamus can be disrupted by PFOA, the underlying molecular mechanisms for the metabolic toxicity of PFOA are not yet clear. These involve epigenetic covalent modifications of histone tails $(15,16)$, small noncoding RNAs that regulate gene expression (17), and DNA methylation (18-20). Modifications in DNA methylation

Corresponding author: Sung-Jin Lee, Kangwon National University College of Animal Life Sciences, Chuncheon 24341, Korea E-mail:sjlee@kangwon.ac.kr patterns lead to developmental reprogramming, and these epigenetic changes can be inherited through cell division (21). In addition, transgenerational exposure to EDCs can affect embryonic cell development through genomic imprinting (22). Previous research has shown that PFOA exposure induces changes in global DNA methylation in human umbilical cord serum (23), mouse embryonic fibroblasts (24), and human hepatocellular carcinoma cells (25), but there have been no studies on the effects of PFOA on global DNA methylation in mouse embryonic hypothalamus cells.

To fill this gap, our study focused on epigenetic toxicity and cytotoxicity of PFOA in mHypoE-N46 cells and its effects on gene expression and how it affects apoptosis, cell cycle, proliferation, and neurotrophic genes. In addition, it looked into its effects on gene modifications of ten-eleven translocation methylcytosine dioxygenases (Tets), DNA methyltransferases (Dnmts) and methyl-CpG binding protein 2 (Mecp2s).

\section{MATERIALS AND METHODS}

\section{Cell culture and reagents}

The mHypoE-N46 (Cellutions Biosystems, Burlington, Canada) cell line, derived from the mouse embryonic hypothalamus was immortalised by retroviral transfer of 
SV40 T-antigen into embryonic mouse hypothalamic primary cell cultures (days 15, 17, and 18) (26). The cells were cultured as a monolayer in Dulbecco's modified Eagle medium (DMEM) with $25 \mathrm{mmol} / \mathrm{L}$ glucose (Sigma-Aldrich, St. Louis, MO, USA) supplemented with $2 \%$ foetal bovine serum (FBS, Gibco, Carlsbad, CA, USA) and $1 \%$ penicillin/ streptomycin (Welgene, Daegu, Korea). The cells were incubated at $37^{\circ} \mathrm{C}$ in $5 \% \mathrm{CO}_{2}$.

PFOA (Sigma-Aldrich) at final concentrations with a 10 -fold difference from 0.25 to $250 \mu \mathrm{mol} / \mathrm{L}$ was dissolved in dimethyl sulphoxide (final concentration $0.1 \%$; SigmaAldrich). Dimethyl sulphoxide (0.1\%) was not toxic to the mHypoE-N46 cells and had no effect on cell survival or ability to divide (data not shown). To eliminate the effects of steroids contained in DMEM and FBS, PFOA treatment was performed in phenol red-free DMEM with $25 \mathrm{mmol} / \mathrm{L}$ glucose (Gibco), supplemented with $1 \%$ charcoal-stripped FBS and $1 \%$ penicillin/streptomycin.

\section{Assessment of cell viability}

The cells were seeded at $5 \times 10^{3}$ cells per well in 96-well plates with $200 \mu \mathrm{L}$ of fresh complete medium and incubated at $37^{\circ} \mathrm{C}$ in $5 \% \mathrm{CO}_{2}$ for $24 \mathrm{~h}$. Cell culture medium $(200 \mu \mathrm{L})$ was then replaced, and PFOA (at final concentrations of 0 , $0.25,2.5,25$, and $250 \mu \mathrm{mol} / \mathrm{L}$ ) was added and incubated for 24 or $48 \mathrm{~h}$. The CellTiter $96^{\circledR}$ non-radioactive cell proliferation assay kit (Promega, Madison, WI, USA) was used according to the manufacturer's protocol. The absorbance was read at $570 \mathrm{~nm}$ using an enzyme-linked immunosorbent assay (ELISA) microplate reader (Molecular Devices, San Jose, CA, USA). The measured optical density values were normalised and cell viability analysed with the GraphPad Prism Software 7.0 (GraphPad Software, San Diego, CA, USA).

\section{$R N A$ isolation and quantitative real-time PCR}

Neurons were harvested and total RNA extracted using the TRIzol reagent (Invitrogen, Carlsbad, CA, USA). Total RNA purity and concentration were quantified with the Nanodrop 2000 spectrophotometer (Thermo Fisher Scientific, Waltham, MA, USA). Quantitative real-time PCR was performed using the iTaq ${ }^{\mathrm{TM}}$ Universal SYBR ${ }^{\circledR}$ Green One-Step kit (Bio-Rad, Foster, CA, USA) with gene- specific primers (Table 1). Data were analysed using the $2^{-\Delta \Delta C T}$ method and transcript levels were normalised to those of the standardisation gene ( $\beta$-actin).

\section{Global DNA methylation assay}

Genomic DNA from mHypoE-N46 was extracted immediately after PFOA treatment using the G-spin ${ }^{\mathrm{TM}}$ Total DNA Extraction Kit (iNtRON Biotechnology, Seongnam, Korea). Total DNA quantity and quality were tested with the Nanodrop 2000 spectrophotometer (Thermo Fisher Scientific). The whole-genome DNA methylation profile was determined using the EpiGentek MethylFlash Global DNA Methylation (5-mC) ELISA Easy Kit (Epigentek, Farmingdale, NY, USA) following the manufacturer's protocols.

\section{Statistical analysis}

Results are presented as mean \pm SEM (standard error of the mean) and analysed with the GraphPad Prism Software 7.0. Statistical significance at $p<0.05$ was determined with one-way ANOVA, followed by a Bonferroni post hoc test. For the calculation of the half maximal inhibitory concentration $\left(\mathrm{IC}_{50}\right)$, we relied on the Quest Graph ${ }^{\mathrm{TM}} \mathrm{IC}_{50}$ Calculator program from the AAT Bioquest website (27).

\section{RESULTS}

\section{Cell viability}

The MTT analysis showed a drop in cell viability in a dose-dependent manner in both 24 and 48-hour PFOA treatment (Figure 1). No statistically significant differences were found between the PFOA concentrations of $0.25 \mu \mathrm{mol} / \mathrm{L}$ and $2.5 \mu \mathrm{mol} / \mathrm{L}$, but they started to show with $25 \mu \mathrm{mol} / \mathrm{L}(\mathrm{p}<0.01)$ and $250 \mu \mathrm{mol} / \mathrm{L}(\mathrm{p}<0.001)$. As 48-hour PFOA treatment showed little difference from the 24-hour treatment, all subsequent experiments were done in cells cultured with PFOA for $24 \mathrm{~h}$. $\mathrm{IC}_{50}$ for 24-hour exposure to PFOA was $27.5 \mu \mathrm{mol} / \mathrm{L}$. Gene expression experiments were therefore performed on cells treated with $2.5 \mu \mathrm{mol} / \mathrm{L}$ and
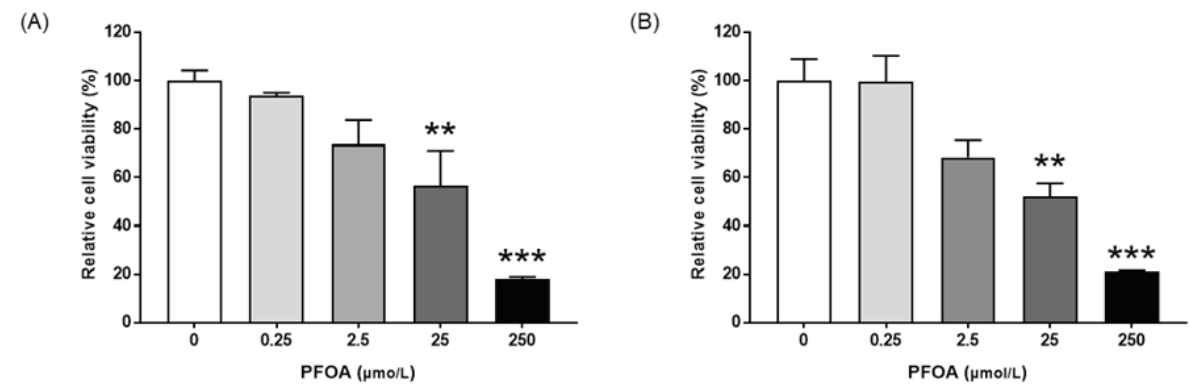

Figure 1 Cell viability of mHypoE-N46 cells following PFOA treatment for (A) $24 \mathrm{~h}$ and (B) $48 \mathrm{~h}$ (MTT assay). Data are shown as mean \pm standard error of triplicate measurements. $* * \mathrm{p}<0.01$ and $* * * \mathrm{p}<0.001$ compared to control 
Table 1 List of primer sequences for quantitative real-time polymerase chain reaction

\begin{tabular}{|c|c|c|c|}
\hline Gene & & Primer sequence $\left(5^{\prime} \rightarrow 3^{\prime}\right)$ & Amplicon size \\
\hline \multirow{2}{*}{$\operatorname{Bax}$} & Forward: & TGCAGAGGATGATTGCTGAC & \multirow{2}{*}{$173 \mathrm{bp}$} \\
\hline & Reverse: & GATCAGCTCGGGCACTTTAG & \\
\hline \multirow{2}{*}{ Casp3 } & Forward: & CTGCCGGAGTCTGACTGGAA & \multirow{2}{*}{$97 \mathrm{bp}$} \\
\hline & Reverse: & ATCAGTCCCACTGTCTGTCTCAATG & \\
\hline \multirow{2}{*}{$\begin{array}{c}\text { Trp73 } \\
(p 73)\end{array}$} & Forward: & AGCCTTTGGTTGACTCCTATCG & \multirow{2}{*}{$119 \mathrm{bp}$} \\
\hline & Reverse: & ACCACCGTGTACCTTGTTCA & \\
\hline \multirow{2}{*}{ Ccna2 } & Forward: & ACCTGCCTTCACTCATTGCT & \multirow{2}{*}{$139 \mathrm{bp}$} \\
\hline & Reverse: & TGGTGAAGGTCCACAAGACA & \\
\hline \multirow{2}{*}{ Ccnbl } & Forward: & CAGTTGTGTGCCCAAGAAGA & \multirow{2}{*}{$216 \mathrm{bp}$} \\
\hline & Reverse: & CTACGGAGGAAGTGCAGAGG & \\
\hline \multirow{2}{*}{ Ccnel } & Forward: & CACCACTGAGTGCTCCAGAA & \multirow{2}{*}{$230 \mathrm{bp}$} \\
\hline & Reverse: & CTGTTGGCTGACAGTGGAGA & \\
\hline \multirow{2}{*}{ Cdknla } & Forward: & GGGATGGCAGTTAGGACTCA & \multirow{2}{*}{$244 \mathrm{bp}$} \\
\hline & Reverse: & GTGGGGCAAGTGCCTAGATA & \\
\hline \multirow{2}{*}{$C d k 4$} & Forward: & CAATGTTGTACGGCTGATGG & \multirow{2}{*}{$178 \mathrm{bp}$} \\
\hline & Reverse: & CAGGCCGCTTAGAAACTGAC & \\
\hline \multirow{2}{*}{ Rps6 } & Forward: & GTCCGCCAGTATGTTGTCAG & \multirow{2}{*}{$103 \mathrm{bp}$} \\
\hline & Reverse: & GTTGCAGGACACGAGGAGTA & \\
\hline \multirow{2}{*}{ Kitl } & Forward: & TCATGGTGCACCGTATCCTA & \multirow{2}{*}{$170 \mathrm{bp}$} \\
\hline & Reverse: & CCTTGGCATGTTCTTCCACT & \\
\hline \multirow{2}{*}{$B d n f$} & Forward: & GGTATCCAAAGGCCAACTGA & \multirow{2}{*}{$183 \mathrm{bp}$} \\
\hline & Reverse: & CTTATGAATCGCCAGCCAAT & \\
\hline \multirow{2}{*}{$\begin{array}{l}\text { Ntrk2 } \\
\text { (TrkB) }\end{array}$} & Forward: & CGCCCTGTGAGCTGAACTCTG & \multirow{2}{*}{$171 \mathrm{bp}$} \\
\hline & Reverse: & CTGCTTCTCAGCTGCCTGACC & \\
\hline Ntrk1 & Forward: & GAGGTCTCTGTCCAAGTCAGCG & $131 \mathrm{hn}$ \\
\hline$(\operatorname{Trk} A)$ & Reverse: & TTGAACAACCAGCGCAGAGA & 101 \\
\hline Nof & Forward: & CAGACCCGCAACATCACTGTA & $131 \mathrm{bp}$ \\
\hline IVg) & Reverse: & CCATGGGCCTGGAAGTCTAG & \\
\hline Tet1 & Forward: & CGAAAGAACAGCCACCAGAT & $219 \mathrm{hn}$ \\
\hline $10 t 1$ & Reverse: & TTGCTCTTCTTCCCCATGAC & $2130 \mathrm{p}$ \\
\hline Tet2 & Forward: & GTTGCAAGAAGAAAGCGGAG & $229 \mathrm{bp}$ \\
\hline $10 t 2$ & Reverse: & CTCTGCCCTTGCTGAAGGT & \\
\hline Tet3 & Forward: & TCCGGATTGAGAAGGTCATC & $176 \mathrm{hn}$ \\
\hline 1Elo & Reverse: & CCAGGCCAGGATCAAGATAA & $1700 \mathrm{p}$ \\
\hline Dnmt1 & Forward: & CCTAGTTCCGTGGCTACGAGGAGAA & $136 \mathrm{bn}$ \\
\hline Drmut & Reverse: & TCTCTCTCCTCTGCAGCCGACTCA & 1000 \\
\hline Dnmt3a & Forward: & CACAGGGCCCGTTACTTCTG & $76 \mathrm{hn}$ \\
\hline Dитила & Reverse: & TCCAGCTTATCATTCACAGTGGAT & $100 \mathrm{op}$ \\
\hline Dnm $3 \mathrm{~h}$ & Forward: & TTCAGTGACCAGTCCTCAGACACGAA & $144 \mathrm{bn}$ \\
\hline DTIIIJU & Reverse: & TCAGAAGGCTGGAGACCTCCСТCTT & \\
\hline Mecn 2 el & Forward: & AGGAGAGACTGGAGGAAAAGT & $70 \mathrm{hn}$ \\
\hline necpz_et & Reverse: & CTTAAACTTCAGTGGCTTGTCT & 100 \\
\hline Mecn2 e? & Forward: & CTCCATAAAAATACAGACTCACCAGT & $183 \mathrm{hn}$ \\
\hline Niecpa_ez & Reverse: & CTTAAACTTCAGTGGCTTGTCT & \\
\hline$\beta$-actin & Forward: & ATGGTGGGAATGGGTCAGAAG & $157 \mathrm{bn}$ \\
\hline p-actinn & Reverse: & CACGCAGCTCATTGTAGAAGG & DP \\
\hline
\end{tabular}


$25 \mu \mathrm{mol} / \mathrm{L}$ of PFOA, whose viability was higher than the $\mathrm{IC}_{50}$.

Effect of PFOA on apoptosis-, cell cycle-, and proliferation-related genes

Because of the previously reported effects of PFOA on cell cycle and proliferation $(25,28-30)$ and the strong effect on cell viability found in this study, we decided to continue by testing several genes related to apoptosis, cell cycle, and proliferation.

Figure 2A shows the expression levels of the apoptotic genes Bax, Casp3, and Trp73. The expression of the Bax gene, which acts as a pro-apoptotic regulator, increased significantly $(\mathrm{p}<0.001)$ upon PFOA exposure in a dosedependent manner, while the Casp3 gene expression in apoptotic cells significantly decreased at $2.5 \mu \mathrm{mol} / \mathrm{L}$ $(\mathrm{p}<0.01)$ and $25 \mu \mathrm{mol} / \mathrm{L}(\mathrm{p}<0.05)$. The mRNA level of the $\operatorname{Trp} 73$ gene, which encodes for the $\mathrm{p} 73$ protein involved in cell-cycle regulation and induction of apoptosis, significantly decreased after exposure to $2.5 \mu \mathrm{mol} / \mathrm{L}(\mathrm{p}<0.05)$ and $25 \mu \mathrm{mol} / \mathrm{L}(\mathrm{p}<0.01)$ of PFOA.

Figure $2 \mathrm{~B}$ shows the expression patterns of three cell cycle-related genes, Ccna2, Ccnb1, and Ccne1. PFOA had no significant effect on Ccna2, but the expression of Ccnb1, which encodes for $\mathrm{G} 2 /$ mitotic-specific cyclin-B1, increased significantly in dose-dependent manner upon exposure to both $2.5 \mu \mathrm{mol} / \mathrm{L}(\mathrm{p}<0.01)$ and $25 \mu \mathrm{mol} / \mathrm{L}(\mathrm{p}<0.001)$ of PFOA. Ccnel gene expression, on the other hand, was downregulated at both PFOA concentrations $(\mathrm{p}<0.01)$.

Figure 2C shows the expression levels of $C d k n 1 a, C d k 4$, Rps6, and Kit1, which are genes related to cell proliferation. The expression of the cyclin-dependent kinase (CDK) inhibitor 1-encoding Cdknla significantly increased in a dose-dependent manner $(\mathrm{p}<0.05$ at $2.5 \mu \mathrm{mol} / \mathrm{L}$ and $\mathrm{p}<0.001$

(A)

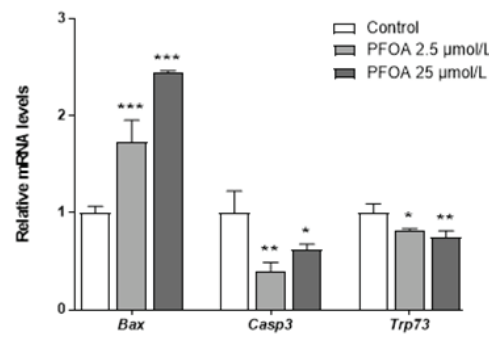

(C) at $25 \mu \mathrm{mol} / \mathrm{L}$ ), but other proliferation gene expressions were not significantly affected.

\section{Effect of PFOA on nerve growth factor-related genes}

In the nerve growth factor - neurotrophic tyrosine kinase receptor type 1 (NGF-NTRK1) neurotrophin system, the gene expression level of the ligand $N g f$ significantly increased $(\mathrm{p}<0.05)$ with exposure to $25 \mu \mathrm{mol} / \mathrm{L}$ of PFOA, unlike the gene expression of receptor Ntrk1 (Figure 3A).

In the BDNF-NTRK2 neurotrophin system, $25 \mu \mathrm{mol} / \mathrm{L}$ of PFOA significantly $(\mathrm{p}<0.01)$ increased the expression of the ligand $B d n f$ gene, while both concentrations significantly increased the expression of Ntrk2, a high-affinity catalytic receptor for several neurotrophins and BDNF $(\mathrm{p}<0.001)$ (Figure 3B).

\section{Epigenetic toxicity of PFOA}

As PFOA showed dose-dependent effects on some genes, we decided to assess global DNA methylation to better understand its effect on genome-wide gene expression. Genome-wide 5-methylcytosine content showed a significant dose-dependent increase compared to control at both PFOA concentrations ( $\mathrm{p}<0.01$ at $2.5 \mu \mathrm{mol} / \mathrm{L}$ and $\mathrm{p}<0.001$ at $25 \mu \mathrm{mol} / \mathrm{L}$ ) (Figure $4 \mathrm{~A}$ ).

To better understand the mechanism of how methylation levels change, we also analysed relative gene expression of Tet1, Tet2, Tet3, Dnmt1, Dnmt3a, and Dnmt3b. Tet1 and Tet 3 increased significantly with both PFOA concentrations $(p<0.001)$, whereas the mRNA expression of Tet 2 significantly decreased at PFOA concentration of $2.5 \mu \mathrm{mol} / \mathrm{L}(\mathrm{p}<0.05)$ (Figure 4B). The expression of Dnmt1 $(\mathrm{p}<0.05)$, Dnmt $3 a$, and Dnmt3b $(\mathrm{p}<0.001)$ significantly decreased at $25 \mu \mathrm{mol} / \mathrm{L}$ of PFOA, while the Dnmt $3 b$ gene
(B)

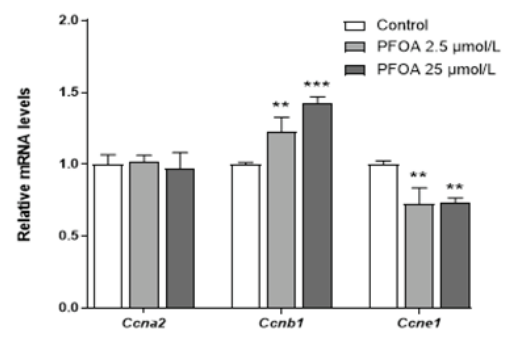

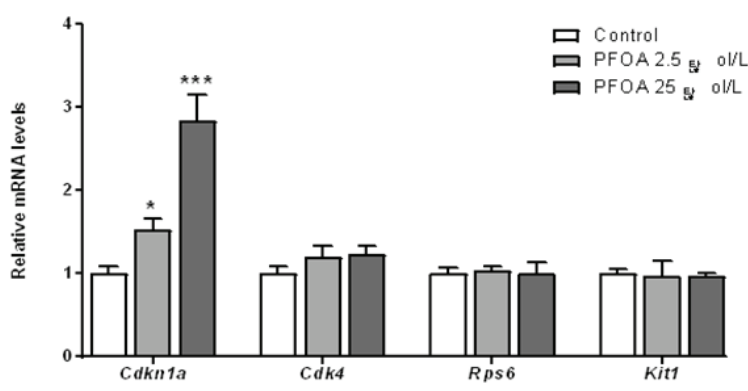

Figure 2 Expression of (A) apoptosis-related genes, (B) cell cycle-related genes, and (C) cell proliferation-related genes after $24 \mathrm{~h}$ of exposure to PFOA (qPCR). Data are shown as mean \pm standard error of three independent measurements. * $\mathrm{p}<0.05$, ** $\mathrm{p}<0.01$, and $* * * \mathrm{p}<0.001$ compared to control 
(A)

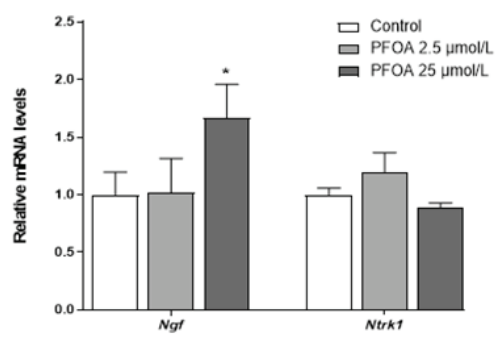

(B)

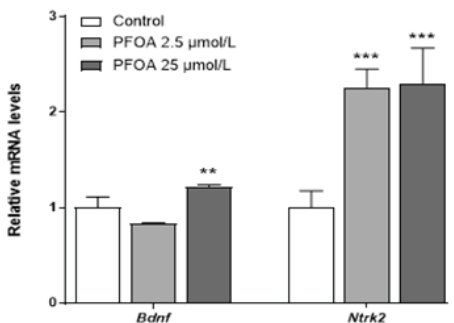

Figure 3 Expression of (A) ligand (Ngf) and receptor (Ntrkl) genes of the NGF-NTRK1 neurotrophin system and (B) ligand (Bdnf) and receptor (Ntrk2) genes of the BDNF-NTRK2 neurotrophin system after $24 \mathrm{~h}$ of exposure to PFOA(PCR). Data are shown as mean \pm standard error of three independent measurements. ${ }^{*} \mathrm{p}<0.05,{ }^{* *} \mathrm{p}<0.01$, and $* * * \mathrm{p}<0.001$ compared to control

expression also significantly decreased at $2.5 \mu \mathrm{mol} / \mathrm{L}$ $(p<0.01)$ (Figure 4C). Finally, in order to investigate the effect of PFOA on CpG-DNA-mediated gene transcription and the involvement of methyl-CpG binding protein, we analysed the changes in gene expression of Mecp 2 isoforms $e 1$ and $e 2$, which are important readers of DNA methylation. The expression of both isoforms, significantly decreased at $2.5 \mu \mathrm{mol} / \mathrm{L}(\mathrm{p}<0.01$ and $\mathrm{p}<0.05$, respectively; Figure 4D)

\section{DISCUSSION}

To determine the effects of PFOA on embryonic hypothalamic cell metabolism, this study evaluated the expression of apoptosis, cell cycle, and cell proliferation genes that play an important role in the development and survival of early neurons. Our results confirmed earlier reports of PFOA cytotoxicity, epigenetic toxicity, and its effects on gene expression and pointed to the mechanisms behind them. The most prominent outcomes of PFOA treatment on mHypoE-N46 cells were a dose dependent drop in cell viability, changes in the expression of some genes related to cell cycle, proliferation, and NGFs, and the activation of apoptosis-related genes. There was a dosedependent increase in global DNA methylation, and a change in the expression of the Tet and Dnmt genes. The expression of the Mecp $2 s$ gene, an important reader of DNA methylation, was reduced.

One of the most important findings of this study is the low PFOA $\mathrm{IC}_{50}$ value $(27.52 \mu \mathrm{mol} / \mathrm{L})$, which clearly suggests that embryonic hypothalamic cells are more sensitive to PFOA toxicity than other tissue cells. In previous studies $(24,25,31,32)$, the PFOA $\mathrm{IC}_{50}$ in other cell types was mostly above $200 \mu \mathrm{mol} / \mathrm{L}$.

Among different genes involved in the neuronal apoptosis mechanism, here we focused on Bax, Casp3 and Trp73 genes. Bax acts as a pro-apoptotic regulator (33). Inactivation of Casp 3 causes a delay in neuronal apoptosis (34), while activation of Trp73 has been implicated in apoptosis induced by abnormal cell proliferation and DNA damage $(35,36)$. We found that exposure to PFOA significantly increased the Bax gene expression in embryonic hypothalamus cells in a dose-dependent manner,
(A)

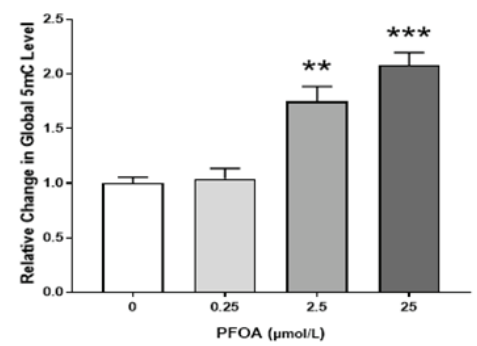

(C)

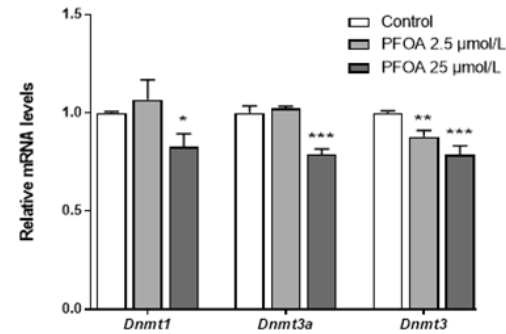

(B)

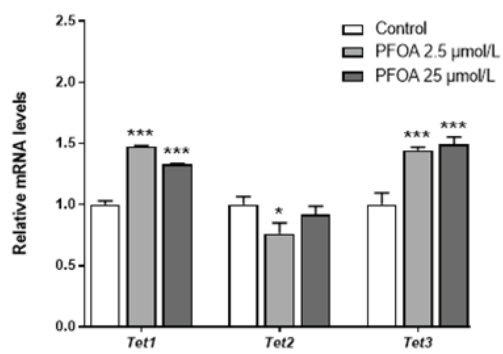

(D)

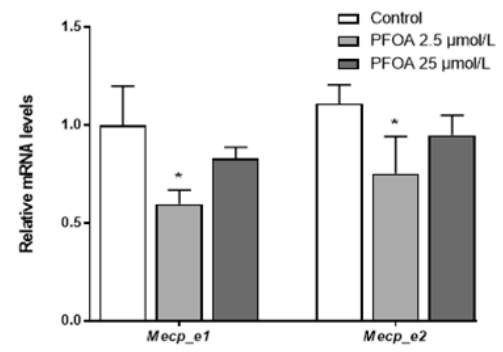

Figure 4 Epigenetic toxicity of PFOA: (A) relative global methylation levels; (B) relative expression of ten-eleven translocation methylcytosine dioxygenase-encoding Tet1, Tet2, and Tet3; (C) relative expression of DNA methyltransferase-encoding Dnmt1, Dnmt3a, and Dnmt3b, and (D) relative expression of methyl-CpG binding protein 2 genes. Data are shown as mean \pm standard error of three independent measurements. ${ }^{*} \mathrm{p}<0.05, * * \mathrm{p}<0.01$, and $* * * \mathrm{p}<0.001$ compared to control 
while the expression of Casp 3 and Trp 73 genes significantly decreased. This decrease in the expression of Casp3 and $\operatorname{Trp} 73$ was consistent with the reports for bisphenol A, another EDC that interferes with developmental processes in the foetal brain (37). Our results confirmed Casp3 and Trp 73-mediated mechanism of PFOA inhibiting apoptosis in embryonic hypothalamus cells, which was consistent with BPA. However, the finding that PFOA led to a dosedependent increase in the Bax gene expression, suggests that Bax-mediated mechanism of apoptosis prevails, despite the delay and suppression mechanisms mediated by Casp3 and $\operatorname{Trp} 73$.

We were also interested in how PFOA affects the cell cycle. We already know that CCNA2 regulates cell cycle progression by interacting with $\mathrm{CDK}$ during both the $\mathrm{G} 1 / \mathrm{S}$ and $\mathrm{G} 2 / \mathrm{M}$ transition phases (38). CCNB1 and CCNE1 are essential for the $\mathrm{G} 2 / \mathrm{M}$ and $\mathrm{G} 1 / \mathrm{S}$ transition, respectively $(39,40)$. Previous studies have shown that exposure to PFOA alters the expression of cyclin-related genes in the human hepatoma cell line (HepG2) and human primary hepatocytes cells (41). With PFOA exposure, such a change in cyclin encoding gene may point to the disturbance in the cell cycle. $C D K N 1 A$ regulates cell proliferation indirectly at the transcriptional level (42-44) or directly through proliferating cell nuclear antigen (45) and binding to CDKs $(46,47)$. Our results showed that the expression of $C d k n 1 a$ significantly increased in all PFOA-treated groups. Overexpression of $\mathrm{p} 21 / C D K N 1 A$ can inhibit cell proliferation (48) and may be involved in apoptosis (49, 50). Overall, since there was no clear association between PFOA exposure and decreased cell viability, it is likely that the change in the expression of the cell homeostasis gene impaired cell viability.

Our study also focused on the neurotrophins, which are important for the survival, development, and function of neurons $(51,52)$, while in embryonic neurons they can regulate apoptosis $(53,54)$. We analysed relative changes in the expression of Ngf, Ntrk1, Bdnf, and Ntrk2 and found that PFOA exposure affected the BDNF-NTRK2 neurotrophin system, as the expression levels of both the ligand Bdnf and the receptor Ntrk2 gene significantly increased. In related studies $(37,55)$, exposure to BPA altered the expression of $N g f$ and $B d n f$ genes, but not of Ntrk1 and Ntrk2. This suggests that changes in ligands of both neurotrophin systems caused by PFOA may follow a mechanism similar to that of BPA. On the other hand, the change in the expression of Ntrk2 suggests that PFOA disrupts the neurotrophin system through a specific mechanism, different from that of BPA. Additionally, these neurotrophin systems can interact with each other to regulate cell survival and death (53). We, therefore, believe that changes in the neurotrophin system caused by PFOA may affect not only growth and development but also survival of embryonic hypothalamic cells.

Our findings have also confirmed that PFOA increases overall DNA methylation in embryonic hypothalamic cells in a dose-dependent manner, unlike previous studies showing reduced global DNA methylation in PFOA-treated HepG2 and human breast epithelial cells (MCF7) $(25,31)$. This can be explained by the reported differences in the patterns of gene expression and epigenetic changes between tissues and cells $(56,57)$.

To evaluate the initiators of the changes in the patterns of DNA methylation after PFOA treatment we focused on Tets (mouse homologue of human TETs) and Dnmts (mouse homologue of human DNMTs). Dnmts and Tet2 expression decreased, while Tet 1 and Tet 3 expression and global DNA methylation increased. This points to a correlation between the level of PFOA exposure and the expression of cell homeostasis and nerve growth factor genes, and suggests that PFOA-induced epigenetic changes may play an important role in altering cell homeostasis and expression of neuronal growth factor genes.

Our findings of significantly downregulated expression of Mecp2_e1 and Mecp2_e2 genes may have wide ramifications, as $\mathrm{MeCP} 2$ not only aids in transcriptional silencing and acts as long-range regulator of methylated genes (58) but it also affects the expression of thousands of genes in the hypothalamus (59).

\section{CONCLUSION}

Overall, our findings suggest that exposure to PFOA affects cell survival through the reprogramming of embryonic hypothalamic DNA methylation patterns and altering cell homeostasis genes. They also suggest that DNA methylation and Mecp 2 gene expression changes induced by PFOA could alter genes of other major mechanisms of the embryonic hypothalamus. All this may serve as a good starting point for further research into the mechanisms of PFOA effects on hypothalamic development.

\section{Acknowledgements}

This study was supported by National Research Foundation of Korea(Project number: 2017R1A2B2012125).

\section{REFERENCES}

1. Lindstrom AB, Strynar MJ, Libelo EL. Polyfluorinated compounds: Past, present, and future. Environ Sci Technol 2011;45:7954-61. doi: 10.1021/es2011622

2. Giesy JP, Kannan K. Perfluorochemical surfactants in the environment. Environ Sci Technol 2002;36:146A-52A. doi: 10.1021/es022253t

3. Schecter A, Colacino J, Haffner D, Patel K, Opel M, Päpke O, Birnbaum L. Perfluorinated compounds, polychlorinated biphenyl, and organochlorine pesticide contamination in composite food samples from Dallas, Texas, USA. Environ Health Perspect 2010;118:796-802. doi: 10.1289/ ehp.0901347

4. Langer V, Dreyer A, Ebinghaus R. Polyfluorinated compounds in residential and nonresidential indoor air. 
Environ Sci Technol 2010;44:8075-81. doi: 10.1021/ es102384z

5. D'Eon JC, Mabury SA. Is indirect exposure a significant contributor to the burden of perfluorinated acids observed in humans? Environ Sci Technol 2011;45:7974-84. doi: 10.1021/es200171y

6. Nicole W. PFOA and cancer in a highly exposed community: New findings from the C8 science panel. Environ Health Perspect 2013;121:A340. doi: 10.1289/ehp.121-A340

7. Apelberg BJ, Witter FR, Herbstman JB, Calafat AM, Halden RU, Needham LL, Goldman LR. Cord serum concentrations of perfluorooctane sulfonate (PFOS) and perfluorooctanoate (PFOA) in relation to weight and size at birth. Environ Health Perspect 2007;115:1670-6. doi: 10.1289/ehp.10334

8. Tao L, Kannan K, Wong CM, Arcaro KF, Butenhoff JL. Perfluorinated compounds in human milk from Massachusetts, USA. Environ Sci Technol 2008;42:3096-101. doi: 10.1021/ es702789k

9. von Ehrenstein OS, Fenton SE, Kato K, Kuklenyik Z, Calafat AM, Hines EP. Polyfluoroalkyl chemicals in the serum and milk of breastfeeding women. Reprod Toxicol 2009;27:239 45. doi: 10.1016/j.reprotox.2009.03.001

10. Llorca M, Farré M, Picó Y, Teijón ML, Alvarez JG, Barceló D. Infant exposure of perfluorinated compounds: levels in breast milk and commercial baby food. Environ Int 2010;36:584-92. doi: 10.1016/j.envint.2010.04.016

11. Brantsæter AL, Whitworth KW, Ydersbond TA, Haug LS, Haugen M, Knutsen HK, Thomsen C, Meltzer HM, Becher G, Sabaredzovic A, Hoppin JA, Eggesbø M, Longnecker MP. Determinants of plasma concentrations of perfluoroalkyl substances in pregnant Norwegian women. Environ Int 2013;54:74-84. doi: 10.1016/j.envint.2012.12.014

12. Russell MH, Waterland RL, Wong F. Calculation of chemical elimination half-life from blood with an ongoing exposure source: The example of perfluorooctanoic acid (PFOA) Chemosphere 2015;129:210-6. doi: 10.1016/j. chemosphere.2014.07.061

13. Legler J, Hamers T, van E van der S de Bor M, Schoeters G, van der Ven L, Eggesbo M, Koppe J, Feinberg M, Trnovec T. The OBELIX project: early life exposure to endocrine disruptors and obesity. Am J Clin Nutr 2011;94:1933S-8S doi: 10.3945/ajen.110.001669

14. Heindel JJ, Newbold R, Schug TT. Endocrine disruptors and obesity. Nat Rev Endocrinol 2015;11:653-61. doi: 10.1038/ nrendo.2015.163

15. Portela A, Esteller M. Epigenetic modifications and human disease. Nat Biotechnol 2010;28:1057-68. doi: 10.1038/ nbt.1685

16. Bannister AJ, Kouzarides T. Regulation of chromatin by histone modifications. Cell Res 2011;21:381-95. doi: 10.1038/cr.2011.22

17. Mattick JS, Makunin IV. Non-coding RNA. Hum Mol Genet 2006;15:R17-29. doi: 10.1093/hmg/ddl046

18. Razin A, Riggs AD. DNA methylation and gene function. Science 1980;210:604-10. doi: 10.1126/science.6254144

19. Robertson KD. DNA methylation and human disease. Nat Rev Genet 2005;6:597-610. doi: 10.1038/nrg1655

20. Kass SU, Pruss D, Wolffe AP. How does DNA methylation repress transcription? Trends Genet 1997;13:444-9. doi: $10.1016 / \mathrm{S} 0168-9525(97) 01268-7$
21. Suvà ML, Riggi N, Bernstein BE. Epigenetic reprogramming in cancer. Science 2013;339:1567-70. doi: 10.1126/ science. 1230184

22. Janesick AS, Shioda T, Blumberg B. Transgenerational inheritance of prenatal obesogen exposure. Mol Cell Endocrinol 2014;398:31-5. doi: 10.1016/j.mce.2014.09.002

23. Guerrero-Preston R, Goldman LR, Brebi-Mieville P, IliGangas C, LeBron C, Witter FR, Apelberg BJ, HernándezRoystacher M, Jaffe A, Halden RU, Sidransky D. Global DNA hypomethylation is associated with in utero exposure to cotinine and perfluorinated alkyl compounds. Epigenetics 2010;5:539-46. doi: 10.4161/epi.5.6.12378

24. Ma Y, Yang J, Wan Y, Peng Y, Ding S, Li Y, Xu B, Chen X, Xia W, Ke Y, Xu S. Low-level perfluorooctanoic acid enhances 3 T3-L1 preadipocyte differentiation via altering peroxisome proliferator activated receptor gamma expression and its promoter DNA methylation. J Anal Toxicol 2018;38:398-407. doi: 10.1002/jat.3549

25. Wen Y, Mirji N, Irudayaraj J. Epigenetic toxicity of PFOA and GenX in HepG2 cells and their role in lipid metabolism. Toxicology in Vitro 2020;65:104797. doi: 10.1016/j. tiv.2020.104797

26. Belsham DD, Cai F, Cui H, Smukler SR, Salapatek AM, Shkreta L. Generation of a phenotypic array of hypothalamic neuronal cell models to study complex neuroendocrine disorders. Endocrinology 2004;145:393-400. doi: 10.1210/ en.2003-0946

27. AAT Bioquest. $\mathrm{IC}_{50}$ calculator, version 1 [displayed 25 june 2021]. Available at https://www.aatbio.com/tools/ic50calculator-v1

28. Hagenaars A, Vergauwen L, Benoot D, Laukens K, Knapen D. Mechanistic toxicity study of perfluorooctanoic acid in zebrafish suggests mitochondrial dysfunction to play a key role in PFOA toxicity. Chemosphere 2013;91:844-56. doi: 10.1016/j.chemosphere.2013.01.056

29. Peng S, Yan L, Zhang J, Wang Z, Tian M, Shen H. An integrated metabonomics and transcriptomics approach to understanding metabolic pathway disturbance induced by perfluorooctanoic acid. J Pharm Biomed Anal 2013;86:5664. doi: 10.1016/j.jpba.2013.07.014

30. Yan S, Zhang H, Zheng F, Sheng N, Guo X, Dai J. Perfluorooctanoic acid exposure for 28 days affects glucose homeostasis and induces insulin hypersensitivity in mice. Sci Rep 2015;5:11029. doi: 10.1038/srep11029

31. Liu W, Irudayaraj J. Perfluorooctanoic acid (PFOA) exposure inhibits DNA methyltransferase activities and alters constitutive heterochromatin organization. Food Chem Toxicol 2020;141:111358. doi: 10.1016/j.fct.2020.111358

32. Pierozan P, Jerneren F, Karlsson O. Perfluorooctanoic acid (PFOA) exposure promotes proliferation, migration and invasion potential in human breast epithelial cells. Arch Toxicol 2018;92:1729-39. doi: 10.1007/s00204-018-2181-4

33. Mignard V, Lalier L, Paris F, Vallette FM. Bioactive lipids and the control of Bax pro-apoptotic activity. Cell Death Dis 2014;5:e1266. doi: 10.1038/cddis.2014.226

34. Cregan SP, MacLaurin JG, Craig CG, Robertson GS, Nicholson DW, Park DS, Slack RS. Bax-dependent caspase-3 activation is a key determinant in p53-induced apoptosis in neurons. J Neurosci 1999;19:7860-9. doi: 10.1523/ JNEUROSCI.19-18-07860.1999 
35. Jost CA, Marin MC, Kaelin Jr WG. p73 is a simian [correction of human] p53-related protein that can induce apoptosis. Nature 1997;389:191-4. doi: 10.1038/38298

36. Stiewe T, Pützer BM. p73 in apoptosis. Apoptosis 2001;6:44752. doi: $10.1023 / \mathrm{a}: 1012433522902$

37. Warita K, Mitsuhashi T, Hoshi N, Ohta K, Suzuki S, Takeuchi Y, Miki T. A unique pattern of bisphenol A effects on nerve growth factor gene expression in embryonic mouse hypothalamic cell line N-44. Arh Hig Rada Toksikol 2014;65:293-9. doi: 10.2478/10004-1254-65-2014-2494

38. Pagano M, Pepperkok R, Verde F, Ansorge W, Draetta G. Cyclin A is required at two points in the human cell cycle. EMBO J 1992;11:961-71. PMCID: PMC556537

39. Ohtsubo M, Theodoras AM, Schumacher J, Roberts JM, Pagano M. Human cyclin E, a nuclear protein essential for the G1-to-S phase transition. Mol Cell Biol 1995;15:2612-24. doi: $10.1128 / \mathrm{mcb} .15 .5 .2612$

40. Brown NR, Lowe ED, Petri E, Skamnaki V, Antrobus R, Johnson L. Cyclin B and cyclin A confer different substrate recognition properties on CDK2. Cell Cycle 2007;6:1350-9. doi: 10.4161/cc.6.11.4278

41. Buhrke T, Krüger E, Pevny S, Rößler M, Bitter K, Lampen A. Perfluorooctanoic acid (PFOA) affects distinct molecular signalling pathways in human primary hepatocytes. Toxicology 2015;333:53-62. doi: 10.1016/j.tox.2015.04.004

42. Engeland K. Cell cycle arrest through indirect transcriptional repression by p53: I have a DREAM. Cell Death Differ 2018;25:114-32. doi: 10.1038/cdd.2017.172

43. Chang BD, Watanabe K, Broude EV, Fang J, Poole JC, Kalinichenko TV, Roninson IB. Effects of p21 $1^{\text {Wafl/Cip//Sdil }}$ on cellular gene expression: Implications for carcinogenesis, senescence, and age-related diseases. Proc Natl Acad Sci USA 2000;97:4291-6. doi: 10.1073/pnas.97.8.4291

44. Ferrandiz N, Caraballo JM, Garcia-Gutierrez L, Devgan V, Rodriguez-Paredes M, Lafita MC, Bretones G, Quintanilla A, Munoz-Alonso MJ, Blanco R, Reyes JC, Agell N, Delgado MD, Dotto GP, León J. p21 as a transcriptional co-repressor of S-phase and mitotic control genes. PLoS ONE 2012;7:e37759. doi: 10.1371/journal.pone.0037759

45. Waga S, Hannon GJ, Beach D, Stillman B. The p21 inhibitor of cyclin-dependent kinases controls DNA replication by interaction with PCNA. Nature 1994;369:574-8. doi: $10.1038 / 369574 \mathrm{a} 0$

46. Xiong Y, Hannon GJ, Zhang H, Casso D, Kobayashi R, Beach D. p21 is a universal inhibitor of cyclin kinases. Nature 1993;366:701-4. doi: 10.1038/366701a0

47. Harper JW, Adami GR, Wei N, Keyomarsi K, Elledge SJ. The 21 Cdk-interacting protein Cip1 is a potent inhibitor of G1 cyclin-dependent kinases. Cell 1993;75:805-16. doi: 10.1016/0092-8674(93)90499-G

48. De Santi M, Galluzzi L, Lucarini S, Paoletti MF, Fraternale A, Duranti A, De Marco C, Fanelli M, Zaffaroni N, Brandi G, Magnani M. The indole-3-carbinol cyclic tetrameric derivative $\mathrm{CTet}$ inhibits cell proliferation via overexpression of p21/CDKN1A in both estrogen receptor-positive and triple-negative breast cancer cell lines. Breast Cancer Res 2011;13:R33. doi: 10.1186/bcr2855

49. Kondo S, Barna BP, Kondo Y, Tanaka Y, Casey G, Liu J, Morimura T, Kaakaji R, Peterson JW, Werbel B, Barnett GH. WAF1/CIP1 increases the susceptibility of p53 nonfunctional malignant glioma cells to cisplatin-induced apoptosis. Oncogene 1996;13:1279-85. PMID: 8808702

50. Kreis NN, Sommer K, Sanhaji M, Kramer A, Matthess Y, Kaufmann M, Strebhardt K, Yuan J. Long-term downregulation of Polo-like kinase 1 increases the cyclindependent kinase inhibitor $\mathrm{p} 21^{\mathrm{WAF} 1 / \mathrm{CIP} 1}$. Cell Cycle 2009;8:460-72. doi: 10.4161/cc.8.3.7651

51. Hempstead BL. Dissecting the diverse actions of pro- and mature neurotrophins. Curr Alzheimer Res 2006;3:19-24. doi: $10.2174 / 156720506775697061$

52. Reichardt LF. Neurotrophin-regulated signalling pathways. Philos Trans R Soc Lond B Biol Sci 2006;29:1545-64. doi: 10.1098/rstb.2006.1894

53. Davey F, Davies AM. TrkB signalling inhibits p75-mediated apoptosis induced by nerve growth factor in embryonic proprioceptive neurons. Curr Biol 1998;8:915-8. doi: 10.1016/s0960-9822(07)00371-5

54. Miller FD, Kaplan DR. Neurotrophin signalling pathways regulating neuronal apoptosis. Cell Mol Life Sci 2001;58:1045-53. doi: 10.1007/PL00000919

55. Warita K, Mitsuhashi T, Ohta K, Suzuki S, Hoshi N, Miki T, Takeuchi Y. In vitro evaluation of gene expression changes for gonadotropin-releasing hormone 1, brain-derived neurotrophic factor and neurotrophic tyrosine kinase, receptor, type 2, in response to bisphenol a treatment. Congenit Anom (Kyoto) 2013;53:42-5. doi: 10.1111/j.1741-4520.2012.00381.x

56. Cheow LF, Courtois ET, Tan Y, Viswanathan R, Xing Q, Tan RZ, Tan DSW, Robson P, Loh Y, Quake SR, Burkholder WF. Single-cell multimodal profiling reveals cellular epigenetic heterogeneity. Nat Methods 2016;13:833-6. doi: 10.1038/ nmeth.3961

57. Cusanovich DA, Hill AJ, Aghamirzaie D, Daza RM, Pliner HA, Berletch JB, Filippova GN, Huang X, Christiansen L, DeWitt WS, Lee C, Regalado SG, Read DF, Steemers FJ, Disteche CM, Trapnell C, Shendure J. A single-cell atlas of in vivo mammalian chromatin accessibility. Cell 2018;174:1309-24. doi: 10.1016/j.cell.2018.06.052

58. Jones PL, Veenstra GJ, Wade PA, Vermaak D, Kass SU, Landsberger N, Strouboulis J, Wolffe AP. Methylated DNA and $\mathrm{MeCP} 2$ recruit histone deacetylase to repress transcription. Nat Genet 1998;19:187-91 doi: 10.1038/561

59. Chahrour M, Jung SY, Shaw C, Zhou X, Wong ST, Qin J, Zoghbi HY. MeCP2, a key contributor to neurological disease, activates and represses transcription. Science 2008;320:1224-9. doi: 10.1126/science.1153252 


\section{Epigenetska toksičnost i citotoksičnost perfluorooktanske kiseline i njezino djelovanje na gensku ekspresiju u stanicama hipotalamusa mišjeg embrija}

Premda je perfluorooktanska kiselina (PFOA) dobro znana kao endokrini disruptor, i dalje se malo zna o mehanizmima u pozadini njezina djelovanja na stanice i njezine toksičnosti u kritičnoj fazi razvoja hipotalamusa. Stoga smo istražili njezino djelovanje u staničnoj liniji N46 hipotalamusa mišjeg embrija (mHypoE-N46) da bismo saznali o mehanizmima kroz koje ih PFOA oštećuje. S tom smo svrhom analizirali vijabilnost stanica, globalnu metilaciju DNA i gensku ekspresiju izloženih stanica. Porastom koncentracija PFOA padala je stanična vijabilnost, a globalna DNA metilacija rasla. Usto je PFOA značajno utjecala na ekspresiju gena povezanih s apoptozom i staničnim ciklusom, neurotrofnih gena te Tet, Dnmt i Mecp2 gena. Naše istraživanje ukazuje na to da izloženost PFOA utječe na preživljenje stanica hipotalamusa mišjeg embrija reprogramiranjem obrazaca metilacije DNA te promjenama u genima zaduženim za održavanje homeostaze. Metilacija DNA i promjene u ekspresiji Mecp2 gena izazvane djelovanjem PFOA također imaju široki spektar implikacija, budući da utječu na promjene u genima zaduženim za druge važne mehanizme u embrijskom hipotalamusu. Stoga naše istraživanje može poslužiti kao dobra polazna točka za daljnje istraživanje mehanizama djelovanja PFOA na razvoj hipotalamusa.

KLJUČNE RIJEČI: citotoksičnost; DNA metilacija; endokrini disruptori; epigenetska toksičnost; mHypoE-N46 stanična linija; PFOA 